\title{
Esophageal Mucoepidermoid Carcinoma
}

National Cancer Institute

\section{Source}

National Cancer Institute. Esophageal Mucoepidermoid Carcinoma. NCI Thesaurus. Code C5343.

A rare carcinoma of the esophagus which contains squamous cells, mucus secreting cells, and cells of an intermediate type. (WHO) 